\title{
Improving Customer Service in Dealing with the Vehicle Routing Problem with Time Windows Using Optimization Algorithms
}

\author{
Muhammad Ihsan JAMBAK ${ }^{1 *}$, Yeshika Kharlina Dranie PUTRI ${ }^{2}$, and Bayu Wijaya \\ PUTRA $^{1}$
}

\author{
${ }^{1}$ Informatics Management Department, Sriwijaya University, Palembang, Indonesia \\ ${ }^{2}$ Informatics Department, Sriwijaya University, Inderalaya, Indonesia \\ *Corresponding author: jambak@unsri.ac.id
}

\begin{abstract}
Vehicle Routing Problem with Time Window (VRPTW) is one of the combinatorial problems faced in serving customers. The Evolution Strategies (ES) and Genetic Algorithm (GA) are part of the artificial intelligence used to solve this problem. Although these techniques are similar, they possess the following differences GA consists of a crossover process while ES is capable of generating new mutations.

Furthermore, ES has advantages over mutations in GA with a rule of $1 / 5$ to obtain better results. Therefore, this study made a comparison between the two algorithms in solving VRPTW cases wherein the distribution of goods need to consider time. Based on the test results on the parameter values, it is seen that GA is better than ES in terms of computation time because the process is faster. However, when viewed from the efficiency of time, ES is better than AG despite its prolonged processing time.
\end{abstract}

Keywords: Vehicle Routing Problem with Time Window, Evolution Strategies Algorithm, Genetic Algorithm,

optimization

\section{INTRODUCTION}

Artificial intelligence is a methodological tool for solving business related problems [1]. For example, late delivery of goods, to destination makes customers complain. However, the solution to such delays is seeking the best routes by considering the distance traveled, vehicles type, capacity, and different locations with minimum costs using Vehicle Routing Problem (VRP). The proper utilization of travel time and goods tends to reduce distribution costs, delay and number of vehicles utilized [2]. In addition, this is also influenced by the constraints which need to follow the time available to the customer known as the Time Window or Vehicle Routing Problem with Time Window (VRPTW). This technique helps to ensure that the distribution of goods does not exceed the time frame, while the customer demands is not greater than the vehicle's capacity. VRPTW is divided into two types, namely the Routing Problem Vehicle with Hard Time Windows (VRPHTW) and the Routing Problem with Soft Time Windows (VRPSTW). VRPHTW is where customers acquire services for the time specified by the them, while on VRPSTW the reverse is the case and when the time limit is exceeded, it results to penalties [3].

The required solution, therefore, is to determine various methods to fulfill requests from customers with the total travel time of the best trip at minimum cost, thereby, eliminating penalties [4]. Minimum costs are represented by total distance and number of vehicles, while cases need to be resolved by considering the suitability of available customer time [5,6]. Genetic Algorithms (GA) and Evolution Strategies (ES) are algorithms, designed to assist VRPTW settlement. GA consists of a crossover process, while ES has no such method in producing a new generation. Furthermore, GA computing time tends to be stable despite the enormous number of nodes, however, its genetic parameters, especially in population size, are very influential in solving cases [7]. While in ES, computational time tends to be unstable and depends on parameter values, especially on the number of generations [5]. ES mutations has $1 / 5$ advantages over mutations in genetic algorithms, and for this reason, it is deemed necessary to compare the two algorithms in solving errors related to VRPTW.

This study focuses on the differences between GA and ES in determining the correct parameter values and time efficiency in solving errors related to VRPTW, in terms of best algorithms. To solve these problems, several research questions were developed, as follows:

How do the AG and ES algorithm work in solving problems related to VRPTW?

Does the AG and ES which depends on parameter value in solving the errors associated with VRPTW, affect the fitness value and its computation?

What is the time efficiency of an AG which uses a crossover compared to ES that uses none?

Genetic Algorithm

Genetic algorithm is part of the evolution algorithm which acts as a search base for natural selection mechanisms and genetics. It also conducts searches for solutions to various 
optimization problems based on existing evolutionary theories [8-10]. The final result of this algorithm is the highest fitness value of all genetic parameters which consists of the following:

Population Size, which consists of the number of individuals involved in each generation,

Crossover Rate (Cr) or Crossover Probability (Pc), which is the possibility of a crossover in a generation,

Mutation Rate (MR) or Probability Mutation (Pm) which is the possibility of mutation or creating a new generation in each individual,

The number of generations formed determines the length of the genetic algorithm process.

The components used to solve a case consist of chromosome formation, initialization, evaluation, calculating fitness functions, and reproduction which comprises of crossover, mutation, and selection. This research uses permutation which is a representation of numbers on genes to illustrate solutions. Initialization will also be used to generate initial populations, which is randomly generated. Furthermore, evaluation is very influential with fitness values because it is used to calculate the functionality of a chromosome.

Based on natural evolution, each individual tends to survive with the possession of a high fitness value, and vice versa [11]. This fitness value is calculated using equation 1 as follows:

fitness $=\frac{1}{\text { aTotalPenalty }+ \text { aTotalDistance }+ \text { aUnserved }}$

where: Total Penalty = sum of time that exceeds the predetermined time limit

Total Distance $=$ the sum of the travel time

Unserved number of customers not served in the distribution due to the imposed penalty

Crossover is a cross-displacement or cross-breeding process which involves two randomly selected parents to obtain a new chromosome [12]. A new individual is produced using a crossover probability multiplied by the population size [4]. In this study, the Partially-Mapped Crossover (PMX) method was used to achieve this, with the mutation process conducted by randomly selecting a parent [11].

Mutation aims to create new individuals from changing or updating one or more genes with a new value that is randomly obtained $[13,14]$. In this study, the production of new individuals was obtained using the probability of mutations multiplied by the size of the population using the reciprocal exchange mutation method [4]. An elitist selection has a trait in choosing individuals with the highest fitness value, those with the lowest score were not selected to survive in the next generation [11].

Evolution Strategies Algorithm

ES has differences with GA in terms of its reproductive process where crossover and mutation serve as supporting and reproductive operators [4]. It uses some notations to denote its parameters namely $\mu$ for population size, $\lambda$ for number of offspring to be produced, and $\sigma$ (strategy parameter) to state the level of mutation randomly conducted.

Furthermore, ES relies more on the mutation process, which is its process type $(\mu, \lambda)$ and $(\mu+\lambda)$. The process $(\mu$, $\lambda$ ) does not involve the individuals' offspring and parent, while the process $(\mu+\lambda)$ involves both. Therefore, this study uses the $(\mu+\lambda)$ process with components almost similar to GA which consist of chromosome formation, initialization, evaluation, calculating fitness functions, and reproduction (mutation and selection). Furthermore, the sub-component explains the chromosome formation, initialization, evaluation, and elitist selection using same formula, with slight differences in the fitness function and mutation. Therefore, this study uses the fitness function in equation 2 , with additional predetermined constant values to obtain better results [6].

fitness $=\frac{1}{(50 \times \text { TotalPenalty })+(0.5 \times \text { TotalDistance })+(50 \times \text { Unserved })}$

The mutation method used in this study is reciprocal exchange, as previously described. The superiority of ES is to have a rule of $1 / 5$, which means the value of $\sigma$ is raised assuming there is at least $1 / 5$ or $20 \%$ of the mutation results from individuals with fitness value higher than the parent, which is increased by multiplying by 1,1 and 0.9 when low[4]. The formulas owned by rule $1 / 5$ is written in equation 3 and the values are recommended around $0.85 \geq$ $\mathrm{a} \leq 1$ assuming the number of generations is greater than 30 [6]. To determine the amount of offspring from the parent $(\lambda)$ on ES using equation 5 where $\mu$ is the population size and $\mathrm{C}$ is a constant value in the form of integers [15].

$$
\begin{gathered}
\sigma=\left\{\begin{array}{lll}
\sigma_{/} a_{s} & \text { jika } & P_{c}<1 / 5 \\
\sigma_{\infty} \omega_{*} & j i k a & P_{c} \geq 1 / 5 \\
\sigma_{x} & j i k a & P_{c}=1 / 5
\end{array}\right. \\
\lambda=\mu * \mathrm{C}
\end{gathered}
$$

Experiments and Result

The data used, were obtained from PT Cahaya Mega Penyimbang which is a gas distribution company in the city of Prabumulih. The data was obtained in March 2017 in the form of customer address, number of individual requests, number of vehicles and its carrying capacity. Meanwhile, the dummy database on informal interviews with distributors, and the distance from one location to another obtained from google maps in kilometers $(\mathrm{km})$, were used to determine the time window and customer service time. Experiments were carried out with ten tests on each of the genetic and strategic parameter values obtain the highest fitness value. The testing stage begins with generation testing, which is carried out to determine the best number of generations or iterations in solving VRPTW cases based on average firmness values and computation time. This test used the elitist selection, with a population size of 50 , combination of crossover and mutation probability values of 0.4: 0.6 , vehicle transport capacity of $1680 \mathrm{~kg}$, with a constant speed at $30 \mathrm{~km} / \mathrm{hr}$.

Table 1 shows the number of generations with best average fitness value of 0.222 , and a computing time of 44.206 seconds from 200 people in the GA test. While table 2 shows the data obtained from the population test results, using a population size of 30 , with an average fitness and computational time of 0.177 and 11.301 respectively from 2000 people. The path choices are obtained because GA requires a large population size to achieve its maximum goal. However, the population size used in this study is 100 with a fitness value of 0.357 , which means that the route is 
duplicated and ineligible in VRPTW cases where the route is visited at least once.

Table 3 shows the data from the test results of the combination of crossover and mutation probability values, with the best average fitness ratio of $0.1: 0.9$, at 0.098 with an average computing time of 12.940 seconds. The testing is conducted to determine the right combination value in solving VRPTW cases. To acquire the optimal results in locating and scheduling the destination, this study uses the elitist selection, generation of 2000, population size of 30 , carrying capacity of $1680 \mathrm{~kg}$, and vehicle speed constant at $30 \mathrm{~km} / \mathrm{hr}$. The computation time is increased by combining the crossover probability and mutation values, which indicates a relatively flat time change. This condition shows that the crossover and mutation probability does not significantly affect computing time, but it dramatically influences the population size and number of generations entered.

Table 1. Number of Generation in Genetic Algorithm

\begin{tabular}{|c|c|c|}
\hline $\begin{array}{c}\text { Number of } \\
\text { Generations }\end{array}$ & $\begin{array}{c}\text { Average of Fitness } \\
\text { Values }\end{array}$ & $\begin{array}{c}\text { Average of Computation } \\
\text { Times (second) }\end{array}$ \\
\hline 500 & 0,059 & 11,732 \\
1000 & 0,063 & 22,771 \\
1500 & 0,089 & 33,095 \\
$\mathbf{2 0 0 0}$ & $\mathbf{0 , 2 2 2}$ & $\mathbf{4 4 , 2 0 6}$ \\
2500 & 0,079 & 54,512 \\
3000 & 0,074 & 66,006 \\
\hline
\end{tabular}

Table 2. Total Population in Genetic Algorithms with 2000 Generations

\begin{tabular}{|c|c|c|c|c|c|}
\hline $\begin{array}{c}\text { Number of } \\
\text { Populations }\end{array}$ & $\begin{array}{c}\text { Average of } \\
\text { Fitness Values }\end{array}$ & $\begin{array}{c}\text { Average of } \\
\text { Computation } \\
\text { Times (second) }\end{array}$ & $\begin{array}{c}\text { Number of } \\
\text { Populations }\end{array}$ & $\begin{array}{c}\text { Average of } \\
\text { Fitness Values }\end{array}$ & $\begin{array}{c}\text { Average of } \\
\text { Computation } \\
\text { Times (second) }\end{array}$ \\
\hline 10 & 0,059 & 2,904 & 60 & 0,096 & 73,139 \\
\hline 20 & 0,070 & 5,609 & 70 & 0,070 & 119,220 \\
\hline $\mathbf{3 0}$ & $\mathbf{0 , 1 7 7}$ & $\mathbf{1 1 , 3 0 1}$ & 80 & 0,115 & 185,800 \\
\hline 40 & 0,175 & 22,370 & 90 & 0,096 & 278,760 \\
\hline 50 & 0,122 & 41,861 & 100 & 0,357 & 403,270 \\
\hline
\end{tabular}

Table 3. Combination of Pc and Pm in Genetic Algorithms with 2000 Generations and 30 Populations

\begin{tabular}{|c|c|c|c|c|c|}
\hline $\begin{array}{c}\text { Combination of } \\
\text { Crossover } \\
\text { Probability Value } \\
: \text { Mutation }\end{array}$ & $\begin{array}{c}\text { Average of } \\
\text { Fitness Values }\end{array}$ & $\begin{array}{c}\text { Average of } \\
\text { Computation } \\
\text { Times (second) }\end{array}$ & $\begin{array}{c}\text { Combination of } \\
\text { Crossover } \\
\text { Probability Value } \\
: \text { Mutation }\end{array}$ & $\begin{array}{c}\text { Average of } \\
\text { Fitness Values }\end{array}$ & $\begin{array}{c}\text { Average of } \\
\text { Computation } \\
\text { Times (second) }\end{array}$ \\
\hline $\mathbf{0 , 1 : 0 , 9}$ & $\mathbf{0 , 0 9 8}$ & $\mathbf{1 2 , 9 0 4}$ & $0,1: 0,1$ & 0,052 & 7,865 \\
\hline $0,2: 0,8$ & 0,057 & 13,015 & $0,2: 0,2$ & 0,066 & 8,916 \\
\hline $0,3: 0,7$ & 0,060 & 12,550 & $0,3: 0,3$ & 0,071 & 9,805 \\
\hline $0,4: 0,6$ & 0,066 & 12,568 & $0,4: 0,4$ & 0,067 & 11,370 \\
\hline $0,5: 0,5$ & 0,083 & 12,225 & $0,6: 0,6$ & 0,076 & 13,875 \\
\hline $0,6: 0,4$ & 0,097 & 12,463 & $0,7: 0,7$ & 0,071 & 15,158 \\
\hline $0,7: 0,3$ & 0,096 & 12,259 & $0,8: 0,8$ & 0,074 & 16,424 \\
\hline $0,8: 0,2$ & 0,085 & 12,613 & $0,9: 0,9$ & 0,077 & 17,557 \\
\hline $0,9: 0,1$ & 0,091 & 12,516 & & & \\
\hline
\end{tabular}

The ES analysis requires input parameters before the algorithm is tested and processed. Each parameter is tested to obtain an effect on the average fitness value and computation time. In table 4, data on the number of generation results, is tested using elitist selection, a population size $(\mu)$ of 50 , offspring $1 \mu$, a truck size of 1680 $\mathrm{kg}$, and a constant vehicle speed of $30 \mathrm{~km} / \mathrm{hr}$. The tests obtained the best number of generations at 2500 with the most significant average fitness value of 181.69 and computing time of 54.14 seconds. 
Table 4. Number of Generations in Evolution Strategies

\begin{tabular}{|c|c|c|}
\hline Number of Generations & $\begin{array}{c}\text { Average of Fitness } \\
\text { Values }\end{array}$ & $\begin{array}{c}\text { Average of Computation Times } \\
\text { (second) }\end{array}$ \\
\hline 500 & 96,89 & 11,63 \\
1000 & 82,26 & 23,42 \\
1500 & 87,93 & 33,96 \\
2000 & 84,64 & 44,68 \\
$\mathbf{2 5 0 0}$ & $\mathbf{1 8 1 , 6 9}$ & $\mathbf{5 4 , 1 4}$ \\
3000 & 85,19 & 64,43 \\
\hline
\end{tabular}

Table 5. Total Population in ES With 2500 Generations and Offspring $1 \mu-10 \mu$

\begin{tabular}{|c|c|c|c|c|c|}
\hline $\begin{array}{l}\text { Number of } \\
\text { Populations }\end{array}$ & $\begin{array}{c}\text { Average of } \\
\text { Fitness Values }\end{array}$ & $\begin{array}{c}\text { Average of } \\
\text { Computation } \\
\text { Times (second) }\end{array}$ & $\begin{array}{l}\text { Number of } \\
\text { Populations }\end{array}$ & $\begin{array}{c}\text { Average of } \\
\text { Fitness Values }\end{array}$ & $\begin{array}{c}\text { Average of } \\
\text { Computation } \\
\text { Times (second) }\end{array}$ \\
\hline \multicolumn{3}{|c|}{$\lambda=1 \mu$} & \multicolumn{3}{|c|}{$\lambda=2 \mu$} \\
\hline 10 & 74,90 & 0,79 & 10 & 88,42 & 0,86 \\
\hline 20 & 84,24 & 3,50 & 20 & 80,95 & 2,73 \\
\hline 30 & 82,76 & 8,21 & 30 & 90,79 & 8,00 \\
\hline 40 & 82,66 & 13,65 & 40 & 82,19 & 11,38 \\
\hline 50 & 86,59 & 31,50 & 50 & 85,56 & 19,67 \\
\hline 60 & 91,60 & 44,22 & 60 & 187,64 & 29,37 \\
\hline 70 & 86,81 & 44,44 & 70 & 91,23 & 45,57 \\
\hline 80 & 87,17 & 47,15 & 80 & 285,29 & 67,87 \\
\hline 90 & 88,79 & 72,23 & 90 & 102,69 & 95,91 \\
\hline 100 & 88,05 & 102,29 & 100 & 287,51 & 135,85 \\
\hline \multicolumn{3}{|c|}{$\lambda=3 \mu$} & \multicolumn{3}{|c|}{$\lambda=4 \mu$} \\
\hline 10 & 82,25 & 1,58 & 10 & 90,72 & 2,54 \\
\hline 20 & 84,55 & 4,56 & 20 & 181,55 & 6,72 \\
\hline 30 & 89,34 & 9,47 & 30 & 93,65 & 17,59 \\
\hline 40 & 280,34 & 18,35 & 40 & 482,39 & 26,93 \\
\hline 50 & 88,11 & 30,35 & 50 & 291,49 & 44,54 \\
\hline 60 & 87,99 & 46,79 & 60 & 88,87 & 70,95 \\
\hline 70 & 92,42 & 79,32 & 70 & 89,94 & 110,67 \\
\hline 80 & 88,94 & 100,04 & 80 & 88,89 & 144,37 \\
\hline 90 & 83,21 & 136,26 & 90 & 90,82 & 321,51 \\
\hline 100 & 100,31 & 190,54 & 100 & 88,46 & 634,53 \\
\hline \multicolumn{3}{|c|}{$\lambda=5 \mu$} & \multicolumn{3}{|c|}{$\lambda=6 \mu$} \\
\hline 10 & 91,13 & 2,58 & 10 & 75,59 & 3,75 \\
\hline 20 & 85,12 & 10,33 & 20 & 90,44 & 13,44 \\
\hline 30 & 88,38 & 26,89 & 30 & 86,11 & 29,19 \\
\hline 40 & 98,60 & 40,64 & 40 & 181,68 & 53,53 \\
\hline 50 & 91,44 & 85,35 & 50 & 88,88 & 93,81 \\
\hline 60 & 86,96 & 103,10 & 60 & 88,25 & 145,46 \\
\hline 70 & 91,75 & 167,68 & 70 & 88,53 & 223,78 \\
\hline 80 & 86,56 & 209,92 & 80 & 138,44 & 293,70 \\
\hline 90 & 86,83 & 288,49 & 90 & 92,90 & 395,88 \\
\hline 100 & 90,21 & 383,37 & 100 & 90,95 & 525,46 \\
\hline \multicolumn{3}{|c|}{$\lambda=7 \mu$} & \multicolumn{3}{|c|}{$\lambda=8 \mu$} \\
\hline 10 & 86,68 & 4,78 & 10 & 87,97 & 5,08 \\
\hline 20 & 86,71 & 17,00 & 20 & 83,03 & 20,57 \\
\hline 30 & 88,75 & 56,41 & 30 & 89,95 & 73,29 \\
\hline 40 & 85,79 & 71,07 & 40 & 89,14 & 93,73 \\
\hline 50 & 86,60 & 150,47 & 50 & 91,85 & 191,45 \\
\hline 60 & 87,73 & 192,58 & 60 & 85,05 & 255,96 \\
\hline 70 & 87,61 & 301,04 & 70 & 87,89 & 411,52 \\
\hline 80 & 88,30 & 396,98 & 80 & 89,03 & 535,83 \\
\hline 90 & 86,20 & 544,72 & 90 & 87,70 & 723,98 \\
\hline 100 & 85,17 & 706,94 & 100 & 88,33 & 952,67 \\
\hline \multicolumn{3}{|c|}{$\lambda=9 \mu$} & \multicolumn{3}{|c|}{$\lambda=10 \mu$} \\
\hline 10 & 81,04 & 10,96 & 10 & 87,16 & 17,16 \\
\hline 20 & 78,20 & 26,129 & 20 & 81,69 & 32,29 \\
\hline 30 & 85,52 & 91,41 & 30 & 87,90 & 134,80 \\
\hline
\end{tabular}




\begin{tabular}{|ccc|ccc|}
40 & 85,86 & 121,00 & 40 & 85,42 & 152,37 \\
50 & 90,30 & 233,89 & 50 & 91,97 & 327,55 \\
60 & 87,68 & 324,51 & 60 & 85,47 & 411,59 \\
70 & 88,36 & 542,24 & 70 & 89,38 & 697,85 \\
80 & 87,55 & 685,14 & 80 & 85,47 & 866,66 \\
90 & 88,24 & 965,06 & 90 & 88,55 & 1327,56 \\
100 & 85,04 & 1217,46 & 100 & 87,60 & 1547,48 \\
\hline
\end{tabular}

In table 5 , the results of the test data obtained significant fitness value using an average computation time of 26.93 seconds, generation number of 2500 , population size of 40 , and an offspring of $4 \mu$ at 482.39 . This result shows a new generation of 160 possible solutions with an average computation time which affects the population size and number of offspring, thereby prolonging the ES process. Furthermore, parameter $\alpha$ was tested to determine values that affect the new generation of mutations in resolving this VRPTW case and reduce computing time. The tests were conducted to obtained optimal results in finding and scheduling the destination, based on the average fitness value and computation time. This test uses elitist selection, with 2500 generations, population size of 40, offspring number of $4 \mu$, vehicle carrying capacity of $1680 \mathrm{~kg}$, and constant speed at $30 \mathrm{~km} /$ hour. Because the number of generations is greater than 30 , the rule $1 / 5$ states that 0.85 $\leq \mathrm{a}<1$ applies, therefore, the $\alpha$ tested is $0.86 ; 0.90 ; 0.95$; and 0.99 .

Table 6 shows that the most significant average fitness value of $\alpha$ obtained at 0.95 is 287.30 , and the average computation time parameter (a) is 131.31 seconds. Furthermore, the average computation time does not change significantly, therefore, in conclusion, the parameter $\alpha$ fails to affect the computing time, number of generations, population size, and the number of offspring.

Table 6. Parameter $\alpha$ Value on ES with 2500 Generations, 40 Populations, and Offspring $4 \mu$

\begin{tabular}{|c|c|c|}
\hline Parameter a & $\begin{array}{c}\text { Average of Fitness } \\
\text { Values }\end{array}$ & $\begin{array}{c}\text { Average of Computation Times } \\
\text { (second) }\end{array}$ \\
\hline 0,86 & 83,47 & 144,47 \\
0,90 & 117,97 & 133,48 \\
$\mathbf{0 , 9 5}$ & $\mathbf{2 8 7 , 3 0}$ & $\mathbf{1 3 1 , 3 1}$ \\
0,99 & 287,28 & 132,28 \\
\hline
\end{tabular}

\section{ANALYSIS}

The test results between the two algorithms are analyzed by dividing the "total travel time for all vehicles" by the "maximum total travel time for all vehicles" as shown in equation 5. In addition, their efficiency level was compared which led to a manual simulation as shown in table 7. The manual calculation was based on the VRPTW concept, with distribution carried out in a day using the search and scheduling routes with an estimated time and distance of the manual process as shown in table 7 .

Eff $=\frac{\sum \mathrm{t}_{\text {vehicle }}}{\sum \mathrm{t}_{\text {max of vehicle }}} \times 100 \%$ $\begin{array}{ll}\text { where: } & \text { Eff }=\text { time efficiency } \\ & \sum \mathrm{t}_{\text {vehicle }}=\text { total travel time of all vehicles } \\ & \sum \mathrm{t}_{\text {max of vehicle }}=\text { maximum total travel time of all } \\ \text { vehicles } & \end{array}$ The VRPTW settlement using GA and ES is shown in table 8 , in the form of distance and time taken on the journey of each vehicle. Furthermore, the VPRTW was processed using a GA with the best parameter values as follows: 2000 number of generations, population size of 30 , and the right combination of crossover probability values and mutations of 0.1: 0.9. VPRTW was also processed using ES with 2500 generations, population size of 40 , number of $4 \mu$ offspring, and parameter values $\alpha$ of 0.95 .

Table 7. Results of Manual Route Scheduling

\begin{tabular}{|c|c|c|c|}
\hline Vehicle \# & \multicolumn{2}{|c|}{ Routes Search \& Scheduling } & $\begin{array}{c}\text { Estimation of } \\
\text { Travelling Distance }\end{array}$ \\
\hline 1 & $\begin{array}{c}0=\text { Jalan Flores Dwikora } 2 \\
16=\text { Jalan Flores } \\
17=\text { Jalan Flores } \\
18=\text { Jalan Flores Leman (Flores 5) } \\
19=\text { Jalan Sukarela } \\
20=\text { Jalan Belitung } \\
28=\text { Jalan Sudirman (Zipur) }\end{array}$ & $\begin{array}{c}21=\text { Jalan Nias } \\
22=\text { Jalan Nusa } 2 \\
12=\text { Stasiun Kereta Api } \\
1=\text { Jln Basuki Rahmat (Padi) } \\
11=\text { Jalan Sosial (Majasari) } \\
0=\text { Jalan Flores Dwikora 2 }\end{array}$ & $\begin{array}{c}30,71 \mathrm{~km} \\
6 \mathrm{hr} . \\
49 \text { minutes }\end{array}$ \\
\hline
\end{tabular}




\begin{tabular}{|c|c|c|c|}
\hline 2 & $\begin{array}{c}0=\text { Jalan Flores Dwikora } 2 \\
2 \text { = Jalan Bakaran } \\
14=\text { Jalan Sudirman Patih Galung } \\
4=\text { Jalan Sudirman (Zipur) }\end{array}$ & $\begin{array}{c}30=\text { Jalan Pipa Bawah Kemang } \\
7=\text { Anak Petai } \\
0=\text { Jalan Flores Dwikora } 2\end{array}$ & $\begin{array}{c}63,2 \mathrm{~km} \\
4 \mathrm{hr} . \\
58 \text { minutes }\end{array}$ \\
\hline 3 & $\begin{array}{c}0=\text { Jalan Flores Dwikora } 2 \\
9=\text { Yayasan Bakti } \\
10=\text { Yayasan Bakti } \\
13=\text { Jalan Urip (Nasional) } \\
5 \text { = Jalan Wonosari } \\
8=\text { Jalan SPM (Wonosari) }\end{array}$ & $\begin{array}{c}32=\text { Jln Prof M. Yamin } \\
33=\text { Wonosari } \\
15=\text { Jln Ade Irma (Batang Asem) } \\
29=\text { Jln Sudirman (Prabu Jaya) } \\
0 \quad \text { = Jalan Flores Dwikora } 2 \\
1\end{array}$ & $\begin{array}{l}18,65 \mathrm{~km} \\
8 \mathrm{hr} \text {. } \\
53 \text { minutes }\end{array}$ \\
\hline 4 & $\begin{array}{c}0=\text { Jalan Flores Dwikora } 2 \\
31=\text { Taman Baka Prabu Jaya } \\
\\
34 \text { = Alai Batu } \\
3 \text { = Tanjung Telang }\end{array}$ & $\begin{array}{c}6 \text { = Padat Karya Gunung Ibul } \\
23=\text { Jalan Lingkar Timur } \\
24=\text { Jalan Lingkar Timur } \\
0=\text { Jalan Flores Dwikora } 2\end{array}$ & $\begin{array}{c}52 \mathrm{~km} \\
4 \mathrm{hr} . \\
12 \text { minutes } \\
\end{array}$ \\
\hline 5 & $\begin{array}{c}0=\text { Jalan Flores Dwikora } 2 \\
25=\text { Cambai } \\
26=\text { Cambai }\end{array}$ & $\begin{array}{c}27=\text { Cambai } \\
0=\text { Jalan Flores Dwikora } 2\end{array}$ & $\begin{array}{l}12,2 \mathrm{~km} \\
1 \mathrm{hr} . \\
34 \text { minutes }\end{array}$ \\
\hline
\end{tabular}

Table 8. Results of the VRPTW Process Optimization by GA and ES

\begin{tabular}{|c|c|c|c|c|c|}
\hline \multicolumn{3}{|c|}{ Using Genetic Algorithm } & \multicolumn{3}{|c|}{ Using Evolution Strategies Algorithm } \\
\hline $\begin{array}{l}\text { Veh } \\
\text { icle } \\
\#\end{array}$ & Routes Search \& Scheduling & $\begin{array}{l}\text { Travelling } \\
\text { Distance } \\
\text { \& Time }\end{array}$ & $\begin{array}{c}\text { Vehic } \\
\text { le \# }\end{array}$ & Routes Search \& Scheduling & $\begin{array}{l}\text { Travelling } \\
\text { Distance \& } \\
\text { Time }\end{array}$ \\
\hline 1 & 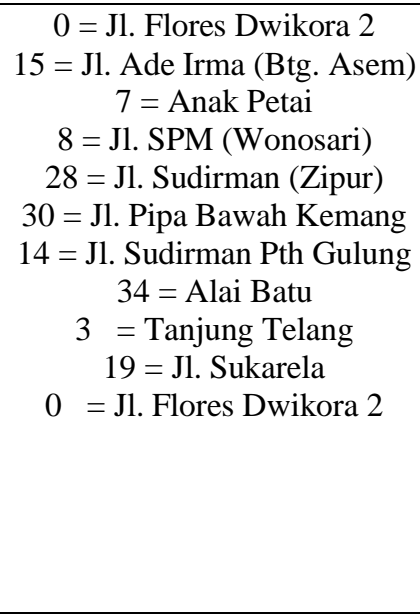 & $\begin{array}{c}69,4 \mathrm{~km} \\
15 \mathrm{hr} \\
52 \text { minutes }\end{array}$ & 1 & $\begin{array}{c}0=\mathrm{Jl} \text {. Flores Dwikora } 2 \\
11=\mathrm{Jl} \text {. Sosial (Majasari) } \\
21=\mathrm{Jl} \text {. Nias } \\
12=\text { Stasiun Kereta Api } \\
\text { (Statsiun Prabumulih Baru) } \\
24=\text { Jl. Lingkar Timur } \\
26=\text { Cambai Prabumulih } \\
19=\text { Jl. Sukarela } \\
14=\text { Jl. Sudirman Pth Galung } \\
30=\text { Jl. Pipa Bawah Kemang } \\
34=\text { Alai Batu } \\
33=\text { Wonosari Prabumulih } \\
3=\text { Tanjung Telang } \\
8=\text { Jl. SPM (Wonosari) } \\
7=\text { Anak Petai } \\
0=\text { Jl. Flores Dwikora } 2\end{array}$ & $\begin{array}{l}111,9 \mathrm{~km} \\
17 \mathrm{hr} . \\
14 \text { minutes }\end{array}$ \\
\hline 2 & $\begin{array}{c}0=\mathrm{Jl} \text {. Flores Dwikora } 2 \\
5=\mathrm{Jl} \text {. Wonosari Prabumulih } \\
32=\mathrm{Jl} \text {. Prof. Moh. Yamin } \\
22=\mathrm{Jl} \text {. Nusa } 2 \\
0=\mathrm{Jl} . \text { Flores Dwikora } 2\end{array}$ & $\begin{array}{l}15,72 \mathrm{~km} \\
1 \mathrm{hr} \\
40 \text { minutes }\end{array}$ & 2 & $\begin{array}{c}0=\mathrm{Jl} \text {. Flores Dwikora } 2 \\
5=\mathrm{Jl} . \text { Wonosari Prabumulih } \\
13=\mathrm{Jl} . \text { Urip (Nasional) } \\
18=\mathrm{Jl} . \text { Flores Leman } 5 \\
16=\mathrm{Jl} . \text { Flores } \\
17=\mathrm{Jl} . \text { Flores } \\
0=\mathrm{Jl} . \text { Flores Dwikora } 2\end{array}$ & $\begin{array}{l}16,96 \mathrm{~km} \\
3 \mathrm{hr} \text {. } \\
12 \text { minutes }\end{array}$ \\
\hline 3 & $\begin{array}{c}0=\text { Jl. Flores Dwikora } 2 \\
33=\text { Wonosari Prabumulih } \\
31=\text { Taman Baka Prabu Jaka } \\
0=\text { Jl. Flores Dwikora } 2\end{array}$ & $\begin{array}{c}15,2 \mathrm{~km} \\
1 \mathrm{hr} \\
14 \text { minutes }\end{array}$ & 3 & $\begin{array}{c}0=\mathrm{Jl} . \text { Flores Dwikora } 2 \\
1=\mathrm{Jl} . \text { Basuki Rahmat (Padi) } \\
10=\text { Yayasan Bakti } \\
9=\text { Yayasan Bakti } \\
32=\mathrm{Jl} . \text { Prof, Moh. Yamin } \\
25=\text { Cambai Prabumulih } \\
0=\mathrm{Jl} . \text { Flores Dwikora } 2\end{array}$ & $\begin{array}{l}26,75 \mathrm{~km} \\
4 \mathrm{hr} . \\
50 \text { minutes }\end{array}$ \\
\hline 4 & $\begin{array}{c}0=\mathrm{Jl} . \text { Flores Dwikora } 2 \\
6=\text { Padat Karya Gunung Ibul } \\
29=\mathrm{Jl} . \text { Sudirman Prabu Jaya } \\
18=\mathrm{Jl} . \text { Flores Leman } 5 \\
0=\mathrm{Jl} . \text { Flores Dwikora } 2\end{array}$ & $\begin{array}{c}13,3 \mathrm{~km} \\
2 \mathrm{hr} \\
53 \text { minutes }\end{array}$ & 4 & $\begin{array}{c}0=\text { Jl. Flores Dwikora } 2 \\
2=\mathrm{Jl} . \text { Bakaran } \\
\begin{array}{c}15=\mathrm{Jl} . \text { Ade Irma (Btg. Asem) } \\
31=\text { Taman Baka Prabu Jaya } \\
0=\mathrm{Jl} . \text { Flores Dwikora } 2\end{array}\end{array}$ & $\begin{array}{l}24,5 \mathrm{~km} \\
2 \mathrm{hr} . \\
50 \text { minutes }\end{array}$ \\
\hline 5 & $\begin{array}{c}0=\mathrm{Jl} . \text { Flores Dwikora } 2 \\
1=\mathrm{Jl} . \text { Basuki Rahmat (Padi) } \\
23=\mathrm{Jl} \text {. Lingkar Timur }\end{array}$ & $\begin{array}{c}35,2 \mathrm{~km} \\
7 \mathrm{hr}\end{array}$ & 5 & $\begin{array}{c}0=\mathrm{Jl} \text {. Flores Dwikora } 2 \\
6 \begin{array}{c}\text { = Padat Karya Gunung Ibul } \\
4 \text { = Gunung Kemala }\end{array}\end{array}$ & $\begin{array}{c}62,6 \mathrm{~km} \\
8 \mathrm{hr} .\end{array}$ \\
\hline
\end{tabular}




\begin{tabular}{|c|c|c|c|c|c|}
\hline & $\begin{array}{c}11=\text { Jl. Sosial (Majasari) } \\
16=\text { Jl. Flores } \\
17=\text { Jl. Flores } \\
21=\text { Jl. Nias } \\
26=\text { Cambai Prabumulih } \\
25=\text { Cambai Prabumulih } \\
27=\text { Cambai Prabumulih } \\
0=\text { Jl. Flores Dwikora } 2\end{array}$ & 19 minutes & & $\begin{array}{c}29=\text { Jl. Sudirman Prabu Jaya } \\
23=\text { Jl. Lingkar Timur } \\
20=\text { Jl. Belitung } \\
27=\text { Cambai Prabumulih } \\
0=\text { Jl. Flores Dwikora } 2\end{array}$ & 25 minutes \\
\hline 6 & $\begin{array}{c}0=\mathrm{Jl} . \text { Flores Dwikora } 2 \\
2=\mathrm{Jl} \text {. Bakaran } \\
12=\text { Stasiun Kereta Api } \\
\text { (Stasiun Prabumulih Baru) } \\
10=\text { Yayasan Bakti } \\
20=\text { Jl. Belitung } \\
24=\mathrm{Jl} . \text { Lingkar Timur } \\
4=\text { Gunung Kemala } \\
0=\mathrm{Jl} \text {. Flores Dwikora } 2\end{array}$ & $\begin{array}{c}60,3 \mathrm{~km} \\
9 \mathrm{hr}\end{array}$ & 6 & $\begin{array}{c}0=\mathrm{Jl} . \text { Flores Dwikora } 2 \\
2=\text { Jl. Bakaran } \\
12=\text { Stasiun Kereta Api } \\
\text { (Stasiun Prabumulih Baru) } \\
10=\text { Yayasan Bakti } \\
20=\text { Jl. Belitung } \\
24=\text { Jl. Lingkar Timur } \\
4=\text { Gunung Kemala } \\
0=\text { Jl. Flores Dwikora } 2\end{array}$ & $\begin{array}{c}6,3 \mathrm{~km} \\
45 \text { minutes }\end{array}$ \\
\hline 7 & $\begin{array}{c}0=\mathrm{Jl} . \text { Flores Dwikora } 2 \\
9=\text { Yayasan Bakti } \\
23=\mathrm{Jl} \text {. Urip (Nasional) } \\
0=\mathrm{Jl} \text {. Flores Dwikora } 2\end{array}$ & $\begin{array}{l}13,85 \mathrm{~km} \\
45 \text { minutes }\end{array}$ & & & \\
\hline
\end{tabular}

Table 9 shows a comparison between the results from the manual calculations and distributors of the VRPTW used to process GA and ES, based on time efficiency. There were differences in the fitness values with additional constant values on the ES which produced better results. A total of five (5) vehicles were produced by manual calculation. However, 13 customers were not served, because the scheduled location does not consider their availability, with gas cylinders delivered according to the location closest to the distribution point (depot). The manual calculation has a time efficiency of $48 \%$, while the VRPTW solution using genetic algorithms is completed with 7 vehicles and 4 unserved customers. Furthermore, VRPTW settlement using ES was completed with 6 vehicles and 4 unserved customers. This result shows that there was a reduction in unserved customers because the distribution takes into account the time available to customers in order to prevent a late delivery time. The number of vehicles used depends on distribution scheduling and requests, which is based on time efficiency, with an increase in the results of VRPTW settlement using ES. Therefore, ES is better with time efficiency of $62.17 \%$ than the GA of $55.29 \%$ and manual calculation of $48 \%$.

Table 9. Comparison of Manual Results with Genetic Algorithms and Evolution Strategies Results

\begin{tabular}{|c|c|c|c|c|}
\hline No. & Observations & $\begin{array}{c}\text { Manual } \\
\text { Calculation }\end{array}$ & Genetics Algorithm & $\begin{array}{c}\text { Evolution Strategies } \\
\text { Algorithm }\end{array}$ \\
\hline 1. & Total of overall visited location & 34 & 34 & 34 \\
\hline 2. & $\begin{array}{l}\text { Number of visited vocations those were } \\
\text { successfully passed }\end{array}$ & 21 & 30 & 30 \\
\hline 3. & Unserved customers & 13 & 4 & 4 \\
\hline 4. & Number of vehicles those used & 5 & 7 & 6 \\
\hline 5. & Population size & - & 30 & 40 \\
\hline 6. & Number of generations & - & 2000 & 2500 \\
\hline 7. & Crossover Probability $(\mathrm{Pc})$ & - & 0,1 & - \\
\hline 8. & $\begin{array}{c}\text { Mutation Probability }(\mathrm{Pm}) / \text { Offspring } \\
(\lambda)\end{array}$ & - & 0,9 & $4 \mu$ \\
\hline 9. & Vehicles Speed Rate & $30 \mathrm{~km} / \mathrm{hr}$ & $30 \mathrm{~km} / \mathrm{hr}$ & $30 \mathrm{~km} / \mathrm{hr}$ \\
\hline 10. & Vehicles Capacity & $1680 \mathrm{~kg}$ & $1680 \mathrm{~kg}$ & $1680 \mathrm{~kg}$ \\
\hline 11. & Fitness Value & - & 0,05816 & 73,6643 \\
\hline 12. & Computation Time & - & 10,814 second & 135,162 second \\
\hline 13. & Total Distance & $176,76 \mathrm{~km}$ & $222,95 \mathrm{~km}$ & $249,01 \mathrm{~km}$ \\
\hline 14. & Time Efficiency & $48 \%$ & $55,29 \%$ & $62,17 \%$ \\
\hline
\end{tabular}


using GA. Therefore, ES is better used than GA, despite its prolonged processing time.

In further research, it is recommended to examine a combination of VRPTW with variations of VRP using GA, $\mathrm{ES}$, hybrid genetic algorithms, or ES with other algorithms to influence time efficiency. It is also recommended to combine these algorithms with random values to improve the mechanism of work processes.

[10] T. S. Widodo, Komputasi Evolusioner (Algoritma Genetik, Pemrograman Genetik, Pemrograman Evolusioner) Yogyakarta: Graha Ilmu, 2012.

[11] D. Sundarningsih, W. Mahmudy, and Sutrisno, "Penerapan Algoritma Genetika untuk Optimasi Vehicle Routing Problem With Time Window (VRPTW) Studi Kasus Air Minum Kemasan.," Jurnal Mahasiswa PTIIK Universitas Brawijaya, vol. 5, 2015.

[12] P. Toth and D. Vigo, The vehicle routing problem. Philadelphia: Society for Industrial and Applied Mathemathics, 2002.

[13] L. W. Pandjaitan, Dasar-Dasar Komputasi Cerdas. Yogyakarta: Penerbit C.V. Andi Offset, 2007.

[14] N. Hijriana, "Penerapan Metode Algoritma Genetika Untuk Permasalahan Penjadwalan Perawat," INFO-TEKNIK, vol. 16, pp. 61-74, 2016.

[15] F. Munawaroh and W. F. Mahmudy, "OPTIMASI DISTRIBUSI PUPUK MENGGUNAKAN EVOLUTION STRATEGIES," Journal of Environmental Engineering and Sustainable Technology, vol. 2, pp. 89-96, 2015.
[6] I. A. Harun, W. F. Mahmudy, and N. Yudistira, "Implementasi evolution strategies untuk penyelesaian vehicle routing problem with time windows pada distribusi minuman soda XYZ'," Jurnal Mahasiswa PTIIK Universitas Brawijaya, vol. 4, 2014.

[7] D. T. Wiyanti, "Algoritma Optimasi Untuk Penyelesaian Travelling Salesman Problem," Jurnal Transformatika, vol. 11, pp. 1-6, 2013.

[8] P. Utami, C. Suhery, and Ilhamsyah, "Aplikasi Pencarian Rute Terpendek Menggunakan Algoritma Genetika (Studi Kasus: Pencarian Rute Terpendek untuk Pemadam Kebakaran Wilayah Kota Pontianak)," Jurnal Coding Sistem Universitas Tanjungpura, vol. 2, pp. 19-25, 2014.

[9] Suyanto, Artificial Intelligence: SearchingReasoning-Planning-Learning (Edisi Revisi), 2nd ed. ed. Bandung: Penerbit Informatika, 2011. 